\title{
ANALYSIS OF THE DETER-MINANT FACTORS OF INDONESIAN TROPICAL TIMBER EXPORT USING GRAVITY MODEL APPROACH
}

\author{
Rahmah Ade Elvi`, Usman Mustafa, Nugroho Agus, Pospos Tamara Husna \\ Master's Program of Agribusiness, Faculty of Agriculture, Syiah Kuala University, \\ Banda Aceh, Indonesia \\ *E-mail: adesinagaade@gmail.com
}

\begin{abstract}
The wealth of Indonesian forest resources in the form of tropical wood is utilized to support the country's foreign exchange income. The biggest export destination countries are China, Japan, the United States, South Korea, and Australia. Panel data during the 2003 to 2017 observation period of the five export destination countries were used. There are differences in the value of exports to each country influenced by several determinant factors, namely the GDP of the exporter, the importer of the GDP, the exporter population, the population of the importer, the exchange rate, and the distance of the exporting country to the importer country. This study aims to figure out the effect of determinants on the value of tropical timber exports using the Gravity Model approach. The results of the analysis show that the variables of exporter GDP, importer GDP, and the exchange rate have a significant positive effect. The exporter population variable and distance have a significant negative impact, while the importer's population variable is insignificantly negative. The slopes and the constants from the largest to the smallest are the exchange rate, exporter GDP, importer GDP, distance, exporter population, and importer population.
\end{abstract}

\section{KEY WORDS}

Export trade, tropical timber, panel data, determinant factors, gravity model.

Indonesia is an archipelago that has a wealth of abundant forest resources. The estimated area of Indonesian tropical forests reaches 109 million hectares. It controls 41 percent of the world market share after Brazil and the Democratic Republic of Congo. It's no wonder Indonesia ranked first in the Asia Pacific region as well as becoming the world's lung (Nandika, 2005).

One of the Indonesian export activities is utilizing the wealth of forest resources, namely abundant tropical wood, to support the acquisition of national income other than from oil and gas. So far, the opportunities for exporting tropical timber commodities and Indonesian wood products are enormous. With the implementation of IPF (Industrial Plantation Forest) and the TLVS (Timber Legality Verification System) policy aimed at ensuring the legality of exported timber and wood products, so that they do not experience export difficulties and maintain natural preservation.

Since 1985 the government has stipulated a prohibition that exported wood is no longer justified in a log condition and is only justified in the form of processed wood such as plywood, sawn timber, other wood products, and pulp for papermaking (Simangunsong, 2004). The increasing need for property is a potential for Indonesia to continue to increase its exports; thus, development in the forestry industry begins with the logging industry, sawmill industry, wood-based panels, secondary wood processing, pulp, and paper industry.

Indonesia is the largest tropical timber-producing country in Southeast Asia, with export value reaching US $\$ 2,000$ million per year while making tropical wood as the second-largest export product after oil. The increase in tropical timber continues to increase due to a rise in local wood demand from Southeast Asian countries, which is estimated to be $6-8 \%$ annually. In 2005 Indonesian sawn wood production was $10.2 \mathrm{~m}^{3}$, which then exported at 2.7 million $\mathrm{m}^{3}$. The main countries importing wood from Indonesia are Japan at $46 \%$, East Asian countries $42 \%$, European society $7 \%$, and the United States at $3 \%$. 
According to the International Science Writers Association (ISWA) data, the main markets for Indonesian wood commodities and tropical wood products are China, Japan, the United States, South Korea, and Australia. This statement is consistent with the Ministry of Environment and Forestry (MOEF) data. Namely, there are ten countries which are the export destinations of Indonesian tropical woods, and this study selects the five biggest countries as export destinations because it has the most import demand for tropical wood commodities. The following are the value of Indonesian tropical wood exports data to the five most significant countries in the past 15 years:

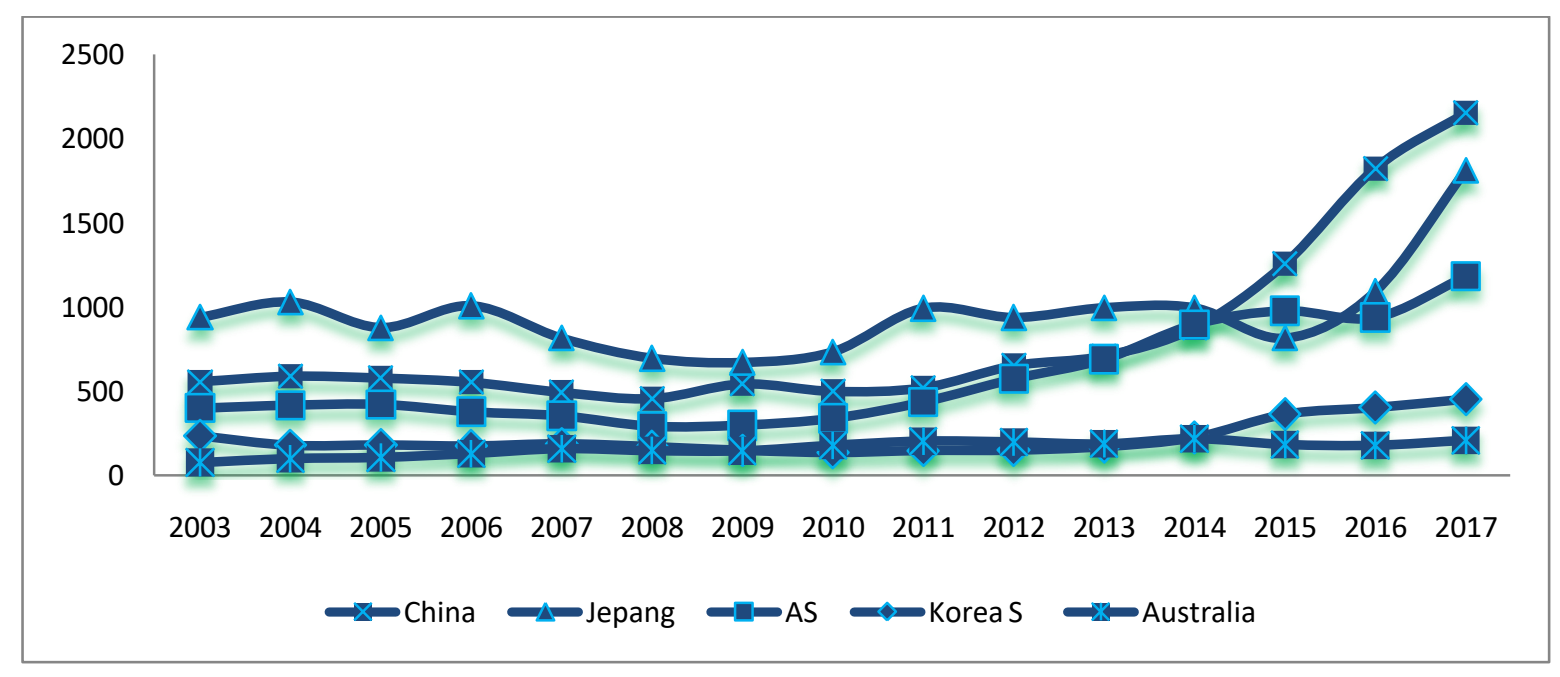

Figure 1 - Indonesian Tropical Timber Exports to the 5 Largest Export Destination Countries in 2003-2017. Source: UN Comtrade Statistic, 2019. Harmonized System Code: 44

The graph above is the export value of five tropical wood importing countries, namely China, Japan, the United States, South Korea, and Australia. China and Japan became the most wood importing countries from Indonesia, followed by the United States, South Korea, and Australia. Based on data obtained from UN Comtrade (2019), the movement of the value of Indonesian tropical timber exports over the past decade has been marked by ups and downs. On average, there was a decline in the number of exports from 2007 to 2008 due to the global financial crisis. Not only were tropical timber commodities affected by the event, but several other export commodities were also affected.

The government continues to find some solutions to increase the quantity and quality of tropical wood products, which can increase the export demand in the international market. In 2015, this was proven by the issuance of Indonesian wood products licensed by FLEGT (Forest Law Enforcement Governance and Trade) as well as being the first country to be entitled to embed the license on timber commodities. FLEGT is a license issued by a legal entity that regulates governance and trade in the forestry sector to help timber-producing countries overcome the problem of illegal logging and increase global exports of legal timber. The result of the hard work has an impact on the value of exports, which continues to grow until 2017, reaching US\$2,154 million, which is an export demand from China. Furthermore, the largest tropical wood exports in a row were Japan at US\$1,813 million, the United States at US $\$ 1,383$ million, South Korea at US $\$ 454$ million, and Australia at US\$210 million.

The difference in the value of exports from various countries is influenced by several determinant factors such as the Gross Domestic Product (GDP) of exporters and importers, the population of exporters and importers, the exchange rate, and the distance between countries that work together. The relationship between these determinants is expected to affect the growth of export demand in a country. Therefore, this study aims to find out how significant the influence of determinant factors on trade interactions between the two countries as well as what factors are dominantly affecting the value of Indonesian tropical timber commodity exports through the Gravity Model approach. 
The gravity model is an analytical technique to measure how several trade factors influence the relationships that occur in a country's bilateral trade. The Gravity Model was first used in the analysis of international trade by Jan Tinbergen (1962) to analyze trade flows between European countries. The use of the Gravity model can predict bilateral trade flows based on the size of the country's economy (such as GDP) and the distance between countries that are geographically different. The distance used is a static distance between the exporting country and the importer country (Head, 2003). The weakness of the gravity model is that when it faced dynamic distance trading, if there is a change in costs, then other trade flows also change, and the explanatory variables in the model cannot explain the cause. Therefore Bergstrand (1985) suggests that variables related to prices should be eliminated. The gravity equation is stated as follows (Sarwoko, 2009).

$$
F_{i j}=G \frac{M_{i} M_{j}}{D^{2} i j}
$$

Where: $F$ is the magnitude of the gravitational force between object $i$ and object $j, G$ is the gravitational constant, $M$ is the mass of the object; $D$ is the distance of object $i$ to object $j$.

Other several popular studies use gravity models to determine trade patterns in various countries as in the following table:

Table 1 - Previous Research Using the Gravity Model

\begin{tabular}{|c|c|}
\hline Theme & Result \\
\hline $\begin{array}{l}\text { Potential Trade in Southeast Europe: a } \\
\text { Gravity Model Approach (Edward, 2005) }\end{array}$ & $\begin{array}{l}\text { The result is national income, both GDP and per capita income, the number of } \\
\text { GDP of trading partners, and geographical distance affect the bilateral trade of } \\
\text { Southeast European countries. }\end{array}$ \\
\hline $\begin{array}{l}\text { ASEAN Free Trade Agreement } \\
\text { Implementation for Indonesian Trading } \\
\text { Performance: A Gravity Model Approach } \\
\text { (Effendi, 2014) }\end{array}$ & $\begin{array}{l}\text { The result shows the GDP, distance, population, exchange rates, tariffs, and } \\
\text { ASEAN membership significantly influence trade with trading partners. In } \\
\text { contrast, the stochastic frontier estimation shows a decrease every year on the } \\
\text { constraints behind the border. }\end{array}$ \\
\hline $\begin{array}{l}\text { Analysis of The Factors Influencing Japan's } \\
\text { Soybean Import Trade (Wang, 2016) }\end{array}$ & $\begin{array}{l}\text { The result shows GDP, trading country population, prices, and exchange rates } \\
\text { have a positive and significant effect on the decline in Japanese soybean } \\
\text { imports, while distance has a negative and significant impact on the decline in } \\
\text { Japanese soybean imports. }\end{array}$ \\
\hline $\begin{array}{l}\text { The Factors Affecting Egypt's Exports: } \\
\text { Evidence from the Gravity Model } \\
\text { Analysis(Elshehawy et al, 2014) }\end{array}$ & $\begin{array}{l}\text { Egypt's GDP, importer GDP, importer population, regional trade agreements, } \\
\text { Egyptian borders with trade partners are the main factors. They have a positive } \\
\text { effect on Egyptian export flows, while transportation costs (distance) have a } \\
\text { negative but not significant effect on Egyptian export flows. }\end{array}$ \\
\hline $\begin{array}{l}\text { A Gravity Model Analysis for Trade } \\
\text { Between Cameroon and Twenty-Eight } \\
\text { European Union Countries (Doumbe and } \\
\text { Belinga, 2015) }\end{array}$ & $\begin{array}{l}\text { The result shows that bilateral trade between Cameroon and } 28 \text { European Union } \\
\text { countries is affected positively and significantly by economic size and GDP per } \\
\text { capita, for the distance between trading partners has a negative effect. }\end{array}$ \\
\hline $\begin{array}{l}\text { The Impact of ASEAN-Korea Free Trade } \\
\text { Agreements on Indonesian Export of } \\
\text { Manufacturing Goods (Mareta, 2018) }\end{array}$ & $\begin{array}{l}\text { All gravity model variables, especially importer GDP, exporter GDP, and } \\
\text { economic openness, have a positive and significant effect on export and import } \\
\text { bilateral trade, the variable distance results vary according to commodity. }\end{array}$ \\
\hline $\begin{array}{l}\text { The Impact of Food Safety Standard on } \\
\text { Indonesian Coffee Exports(Nugroho, 2014) }\end{array}$ & $\begin{array}{l}\text { The GDP and production variables remain essential factors. Still, the regulation } \\
\text { of ochratoxin, which is complied with by the importing country, has a significant } \\
\text { impact on Indonesian coffee trade compared to country-specific regulations, } \\
\text { especially in the case of carbaryl and bilateral negotiations can minimize the } \\
\text { effects of country-specific regulations. }\end{array}$ \\
\hline $\begin{array}{l}\text { The gravity Model of Indonesian Bilateral } \\
\text { Trade (Wahyudi, 2015) }\end{array}$ & $\begin{array}{l}\text { The result shows constant GDP, GDP per capita, and the real effective } \\
\text { exchange rate has a positive and significant effect on Indonesian exports, while } \\
\text { the variable transportation costs (distance) have a negative and significant } \\
\text { impact. }\end{array}$ \\
\hline
\end{tabular}

\section{MATERIALS AND METHODS OF RESEARCH}

The focus of this research was Indonesian bilateral relations with several export destination countries, namely China, Japan, the United States, South Korea, and Australia. The object of the research was Indonesian tropical timber export commodities. The scope of this study covered the analysis of the determinants of Indonesian tropical timber exports using the Gravity Modle approach. The determinants include the GDP of the exporting country, the GDP of the importing country, the population of the exporting population, the 
population of the importer population, the exchange rate, and the static distance of Indonesia and trading partners.

This study used panel data that combines Time Series data for 15 years, namely from 2003 to 2017 and Cross Section data from 5 importing countries, namely China, Japan, the United States, South Korea, and Australia. The sources of data in this research were obtained from several sources, namely for the GDP exporter $\left(G P_{\text {et }}\right)$ and GDP importer $\left(G P_{i t}\right)$ taken from the World Development Indicator (WDI) measured in billions of US dollars. The exporter population ( $\left(\mathrm{POP}_{\mathrm{et}}\right)$, and the population of importers ( $\mathrm{POP}_{\mathrm{it}}$ ) taken from WDI in soul units, the exchange rate (RER $\left.R_{\text {eit }}\right)$ taken from several sources, namely WDI, Bank Indonesia, and Penn World Table 9.1, converted to US Dollars. The distance between countries (DIST ei ) is taken from Cepii Geodist 2019 expressed in units of miles.

Djalal (2006) stated that in panel data processing, there are three models of panel data analysis techniques, namely the Common Effect Model (Ordinary Least Square), Fixed Effect Model (FEM), and Random Effect Model (REM). It is to determine the best model using two processing techniques, namely the Chow Test and the Hausman Test, based on the established decision criteria. The use of STATA software is expected to provide estimation results based on panel data conditions used in the study. Furthermore, an analysis was conducted to see the effect of determinants on the value of tropical timber exports by using the Gravity Model approach. The Gravity Model equation can be estimated using the logarithm plus the error term as follows:

$$
\mathrm{X}_{\mathrm{ei}}=\beta_{0}+\beta_{1}\left(\mathrm{Y}_{\mathrm{et}}\right)+\beta_{2}\left(\mathrm{Y}_{\mathrm{it}}\right)+\beta_{3} \mathrm{RER}_{\mathrm{eit}}+\beta_{4} \mathrm{POP}_{\mathrm{et}}+\beta_{5} \mathrm{POP}_{\mathrm{it}}+\beta_{6} \mathrm{DIST}_{\mathrm{ei}}+\varepsilon_{\mathrm{ei}}
$$

$X$ represents the value of tropical timber exports; e, i, t respectively represent exporting countries, importing countries, and trade years of each country. $\beta 0$ is a constant; $\beta \mathrm{s}(\beta 1, \beta 2$, ... $\beta 5)$ are the determinant coefficients; $\varepsilon$ ei is the error term, $Y$ is the total GDP of the exporting and importing countries; RER is the exchange rate; POP represents the country's population, and DIST illustrates the distance of exporters and importers.

Table 2 - Results and Signs Expectations

\begin{tabular}{|c|c|c|c|}
\hline Variable & Implication & $\begin{array}{c}\text { Symbol } \\
\text { Expectation }\end{array}$ & Assumption Theory \\
\hline$Y_{\text {et }}$ & $\begin{array}{l}\text { Total country GDP e } \\
\text { (exporters) in year t }\end{array}$ & + & $\begin{array}{l}\text { Having a positive relationship with trade, the higher the } \\
\text { GDP is, the greater the production capacity will be so that } \\
\text { the exports will increase. }\end{array}$ \\
\hline$Y_{\text {it }}$ & $\begin{array}{l}\text { Total GDP of country i } \\
\text { (importer) in year t }\end{array}$ & + & $\begin{array}{l}\text { Measuring the absorption capacity of the importing } \\
\text { country, GDP, and absorption capacity increases, imports } \\
\text { also increase. }\end{array}$ \\
\hline RER $_{\text {eit }}$ & $\begin{array}{c}\text { The real exchange } \\
\text { rates of countries e and } \\
\mathrm{i} \text { in year } \mathrm{t}\end{array}$ & + & $\begin{array}{l}\text { The higher the exchange rate of a country, the lower the } \\
\text { import value of the destination country because the price } \\
\text { of imported goods is higher }\end{array}$ \\
\hline POPet & $\begin{array}{l}\text { Total population of the } \\
\text { country e (exporters) in } \\
\text { year t }\end{array}$ & - & $\begin{array}{l}\text { The population of the large exporter country, but the } \\
\text { production does not vary so that it meets the needs from } \\
\text { outside, the import is high compared to exports. }\end{array}$ \\
\hline POPit & $\begin{array}{l}\text { Total population of } \\
\text { country i (importer) in } \\
\text { year t }\end{array}$ & + & $\begin{array}{l}\text { The size of the population of trading partners shows a } \\
\text { significant market potential if the population increases the } \\
\text { trade increases. }\end{array}$ \\
\hline DISTet & $\begin{array}{l}\text { The dynamic distance } \\
\text { of country e to } \mathrm{i}\end{array}$ & - & $\begin{array}{l}\text { The distance will increase transportation costs so that it } \\
\text { will reduce trade. }\end{array}$ \\
\hline
\end{tabular}

\section{RESULTS AND DISCUSSION}

The result of the Chow test compares F-tables and F-statistics to determine the OLS or FEM model more precisely, where Ho is OLS, and Ha is FEM. If the P-value (Prob> F) $<$ (Alpha 0.05) then Ha is accepted, the best estimation model is the Fix Effect Model and vice versa. Whereas the Hausman test statistic follows the Chi-Square distribution to determine 
the choice between FEM or REM models where Ho is REM and Ha is FEM. The following is a table of test results for model selection for panel data processing

Table 3 - The Results of the Chow Test and Hausman Test

\begin{tabular}{lllll}
\hline \hline \multirow{2}{*}{ No } & Type of Test & Test Value & \multirow{2}{*}{$<<5 \%$} & Prob. \\
\cline { 2 - 5 } 1 & Chow Test (Prob>F) & 39,15 & 0,05 & 0,0000 \\
2 & Hausman Test (Prob>chi2) & 33,30 & 0,05 & 0,0000 \\
\hline \hline
\end{tabular}

Source: Regresi STATA, 2019.

According to the estimated Chow Test, the probability value $F$ (Prob $>F)<(\alpha<5 \%)$ is equal to 0.0000 , the results show a more appropriate Fixed Effect Model. Furthermore, the Hausman Test estimation results show the value (Prob> chi2) $<(\alpha<5 \%)$ that is equal to 0.0000 . Corresponding with the criteria previously stated, $\mathrm{Ha}$ is accepted, and Ho is rejected, so the most suitable model for the panel data estimation method is the Fixed Effect Model. These results are in line with the statements proposed by several economists namely: (1) if the panel data in the study has a greater time (t) period than the number of individuals it is advisable to choose the Fixed Effect Model processing method; (2) if the panel data in the study has the number of individuals $(n)$ more than the time period $(t)$ then it is recommended to use the Random Effect Model (Djalal, 2006). The following are the results of the estimation of determinants exports using the gravity model approach.

Table 4 - The Results Estimation of Determinants Exports Using the Gravity Model Approach

\begin{tabular}{|c|c|c|c|}
\hline \multirow{2}{*}{$\begin{array}{c}\text { Dependent Variable } \\
\text { Export }\end{array}$} & OLS & Fixed Effect & Random Effect \\
\hline & 1 & 2 & 3 \\
\hline GDP_Eks & $\begin{array}{l}0.00939^{\star \star *} \\
(0.00167)\end{array}$ & $\begin{array}{l}0.00753^{\star \star \star} \\
(0.00159)\end{array}$ & $\begin{array}{l}0.00967^{\star \star \star} \\
(0.00175)\end{array}$ \\
\hline GDP_Imr & $\begin{array}{l}0.000204^{\star \star *} \\
(0.0000146)\end{array}$ & $\begin{array}{l}0.000270^{\star} \\
(0.000105)\end{array}$ & $\begin{array}{l}0.000208^{\star \star \star} \\
(0.0000165)\end{array}$ \\
\hline POP_Eks & $\begin{array}{l}-128.5^{\star \star *} \\
(24.15)\end{array}$ & $\begin{array}{l}-96.16^{\star \star \star} \\
(20.49)\end{array}$ & $\begin{array}{l}-124.9^{\star \star *} \\
(22.93)\end{array}$ \\
\hline POP_imr & $\begin{array}{l}-0.300^{\star * *} \\
(0.0620)\end{array}$ & $\begin{array}{l}-3.527 \\
(8.742)\end{array}$ & $\begin{array}{l}-0.358^{* *} \\
(0.121)\end{array}$ \\
\hline RER & 39818,4 & $\begin{array}{l}398181043.4^{*} \\
(75651.4)\end{array}$ & $\begin{array}{l}48550530.4 \\
(87149932.2)\end{array}$ \\
\hline Dist & $\begin{array}{l}-347381.8^{* * *} \\
(27573,9)\end{array}$ & $\begin{array}{l}-358947.5^{\star} \\
(203892.4)\end{array}$ & $\begin{array}{l}-352706.2 .4^{* * *} \\
(29314.5)\end{array}$ \\
\hline _cons & $\begin{array}{l}2.51818 \mathrm{e}+10^{* * *} \\
(4.01324 \mathrm{E}+9)\end{array}$ & $\begin{array}{l}1.95855 \mathrm{e}+10^{* * *} \\
(3.96257 \mathrm{e}+09)\end{array}$ & $\begin{array}{l}2.44899 \mathrm{e}+10^{* * *} \\
(4.22030 \mathrm{e}+09)\end{array}$ \\
\hline $\mathrm{N}$ & 75 & 75 & 75 \\
\hline R-sq & 0.846 & 0.786 & 0.811 \\
\hline adj.R-sq & 0.835 & 0.752 & \\
\hline
\end{tabular}

Standard errors in parentheses.

${ }^{\star} p<0.05,{ }^{* *} p<0.01,{ }^{* * *} p<0.001$

Note: Chow Test Results (Prob> $F=0.0000$ ) and Hausman Test Results (Chi2 $=33.30$ and Prob $>$ chi2 $=0.0000$ ) shows that Random Effect estimates are not consistent.

The estimation results in the table above show that the gravity model can give the expected results. Regarding the regression coefficient, it shows the overall results agreed Gravity-Model theory. Some variables in the model can provide significant added value but are negative, and there are also variables in the model that are not significant but positive. The panel test results previously obtained a coefficient of determination $\left(R^{2}\right)$ of 0.846 , which means that the independent variables in the study can explain about $84.6 \%$ of the diversity of the value of Indonesian tropical timber exports to 5 export destination countries while other factors beyond the model influence the remaining $15.4 \%$. 
According to the estimated results using Fixed Effect Model, the coefficient values for all independent variables in the study can be formulated as follows:

$$
\begin{aligned}
& X_{\text {ei }}=1.958+0,00753\left(G P_{\text {et }}\right)+0.000270\left(G P_{i t}\right)-96,16 P P_{\text {et }}-3,527 P P_{i t}+39818,4 R E R_{\text {eit }}- \\
& 358947,5 \text { DIST }_{\text {ei }}
\end{aligned}
$$

The formulation of the gravity model above indicates the second hypothesis in the study does not match the results. The estimation result shows positive determinants of the value of Indonesian tropical timber exports estimates of export destination countries are the exchange rate, export GDP, and importer GDP. Furthermore, the population of exporters and the distance between exporting and importing countries have a significant negative effect, whereas the positive importer population does not significantly influence the export value. Thus, it can be consecutively written that the dominant influencing factors are the exchange rate, GDP of exporters, GDP of importers, distance, the population of exporters, and the population of importers.

The exporters' GDP values have a positive relationship with trade. If the value of the GDP of the exporting country increases, it means that the production capacity will also be higher so that tropical timber exports will increase. The estimation result shows the effect of GDP exporters on the value of tropical timber exports to five export destination countries is significantly positive, with a probability value of 0,000 (significant level $\alpha=0.001$ ). The coefficient of exporters' GDP is positive with 0.00753 , meaning that for every $1 \%$ increase in exporters' GDP, the value of exports will increase by $0.00753 \%$. The following is a graph that illustrates the acceptance of Indonesian real GDP from 2003 to 2017 is as follows:

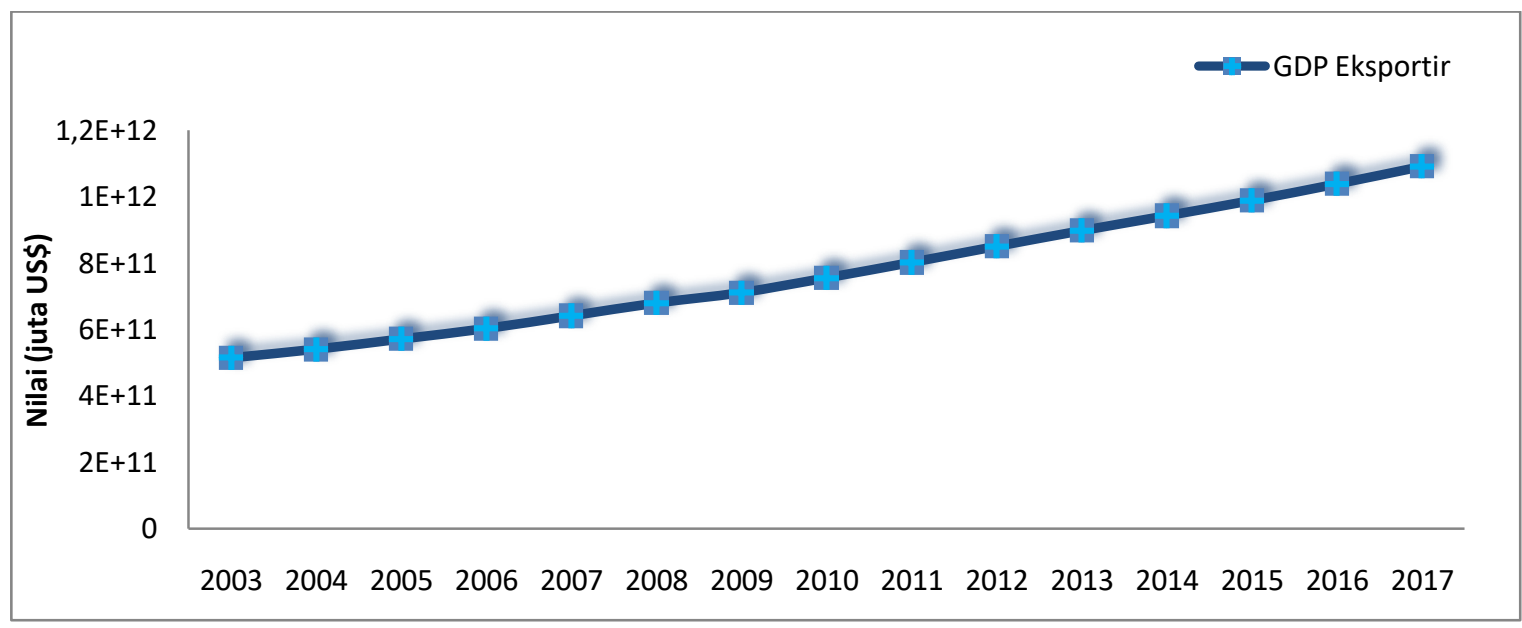

Figure 2 - The Exporters' GDP from 2003-2017

The graph above illustrates the GDP of Indonesia, which continued to increase from 2003 to 2017. In 2017, the GDP reached about US\$1,090 million. It means that the greater increase in GDP, Indonesia will automatically enlarge the capacity of tropical wood production to increase its ability to supply timber needs to the world.

\section{The importing Country's GDP}

The GDP of the importing country can describe the amount of absorption capacity of a said country. An increase in people's income causes an increased acquisition of the country's GDP; automatically, a country's consumption needs will also increase so that it encourages demand and supply in the market. Based on the estimation result, it shows that the importer's GDP influences the export value with a positive marked coefficient of 0.000270 with a probability value of $(0.012)$ and a significant level $\alpha=0.05$, means that every $1 \%$ increase in the value of the importer GDP will increase the number of tropical timber exports 
by $0.000270 \%$. To see the GDP number of the five export destination countries, the researcher has described them in the graph below:

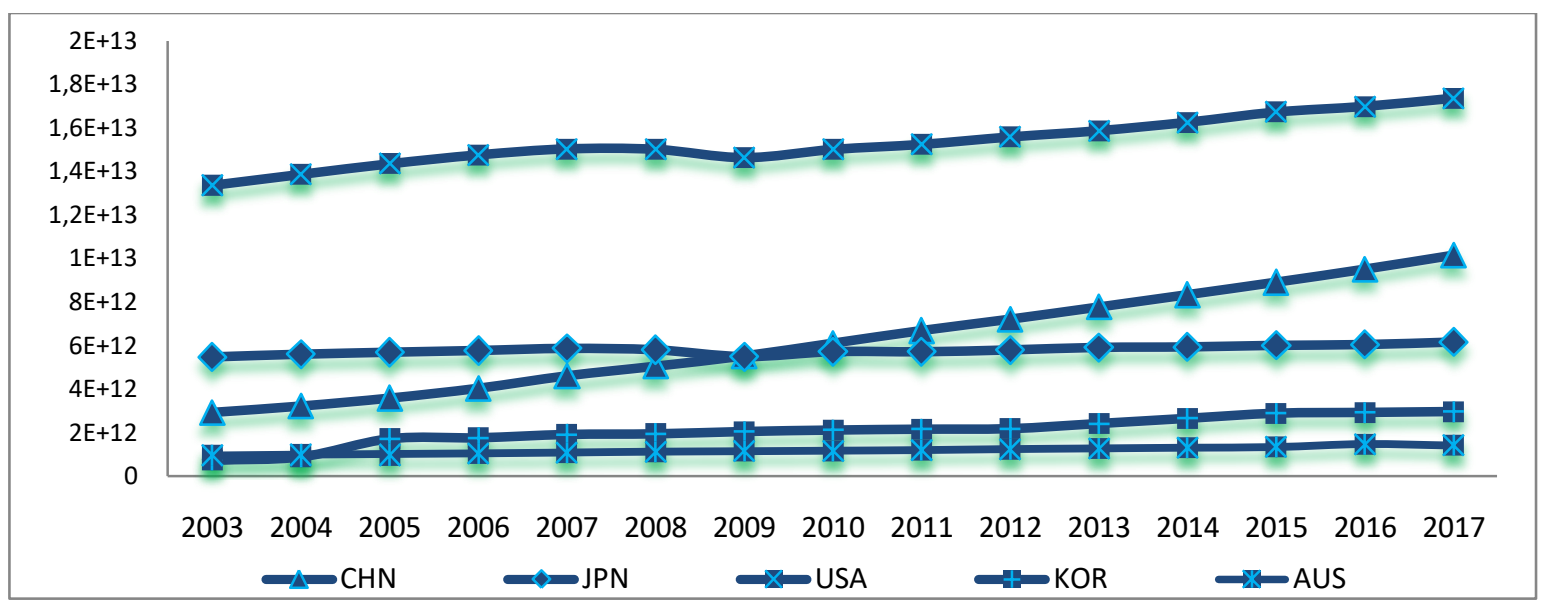

Figure 3 - The importers' GDP from 2003-2017

The figure above shows the national income of the countries that are Indonesian export destinations, namely China, Japan, the United States, South Korea, and Australia. In general, the acquisition of GDP of importing countries from 2003 to 2017 continues to increase. The United States occupied the top position with the acquisition of GDP of US\$17 trillion in 2017 and followed by China, Japan, South Korea, and Australia with the acquisition of GDP of 10 trillion US\$6 trillion, US\$3 trillion and US\$1,4 trillion in 2017.

Population is the total number of people who inhabit the country in a certain period of time expressed in units of soul. According to the estimation results, the direction of the exporter population variable is negatively correlated with the significantly negative coefficient, which is (-96.159) with a probability smaller than the real level $\alpha=0.01, \alpha=0.05, \alpha=0.001$ which is equal to 0.000 . These results mean that when the total population of exporters increases by $1 \%$, it will reduce the number of tropical wood exports by $96.159 \%$. In other words, the increasing population of Indonesia has led to an increase in the amount of consumption so that the Indonesian state must reduce the number of exports to meet domestic needs. The following is the data of the Indonesian population from 2003 to 2017:

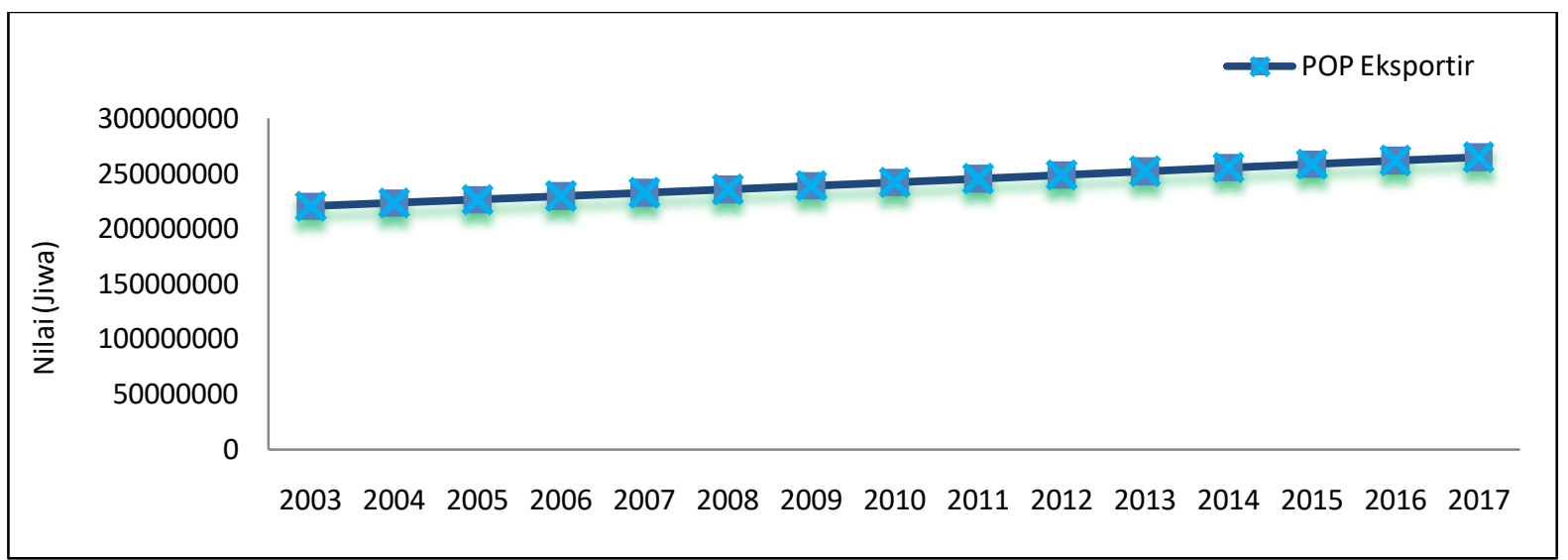

Figure 4 - The Exporters' Population from 2003-2017

From figure 6, it can be seen that the population of Indonesia continues to grow each year, reaching 264 million in 2017, which means that it is classified as a densely populated country. Indonesia also occupies the number four position in the world with the largest population. Nevertheless, the population of Indonesia as a tropical timber exporting country 
has a negative effect on the export of tropical wood because of the country's large population but not so diverse production. Goods must be imported to meet the needs of the community, which result in higher imports than exports value.

The population of the importing country is positively related to trade. The more population a country has will increase the import quantity of the country due to the increasing need of the community for a property. Based on the estimation results for the importing population variable, the trade direction does not match the theory and hypothesis. The coefficient is negative (-3.526) and not significant because the probability value is greater than the level of confidence $\alpha=0.01, \alpha=0.05$, which is 0.688 . In other words, increasing the number of importers by $1 \%$ will reduce import demand by $3.526 \%$ insignificantly. The following is a graph of the total population of importing countries from 2003 to 2017 as follows:

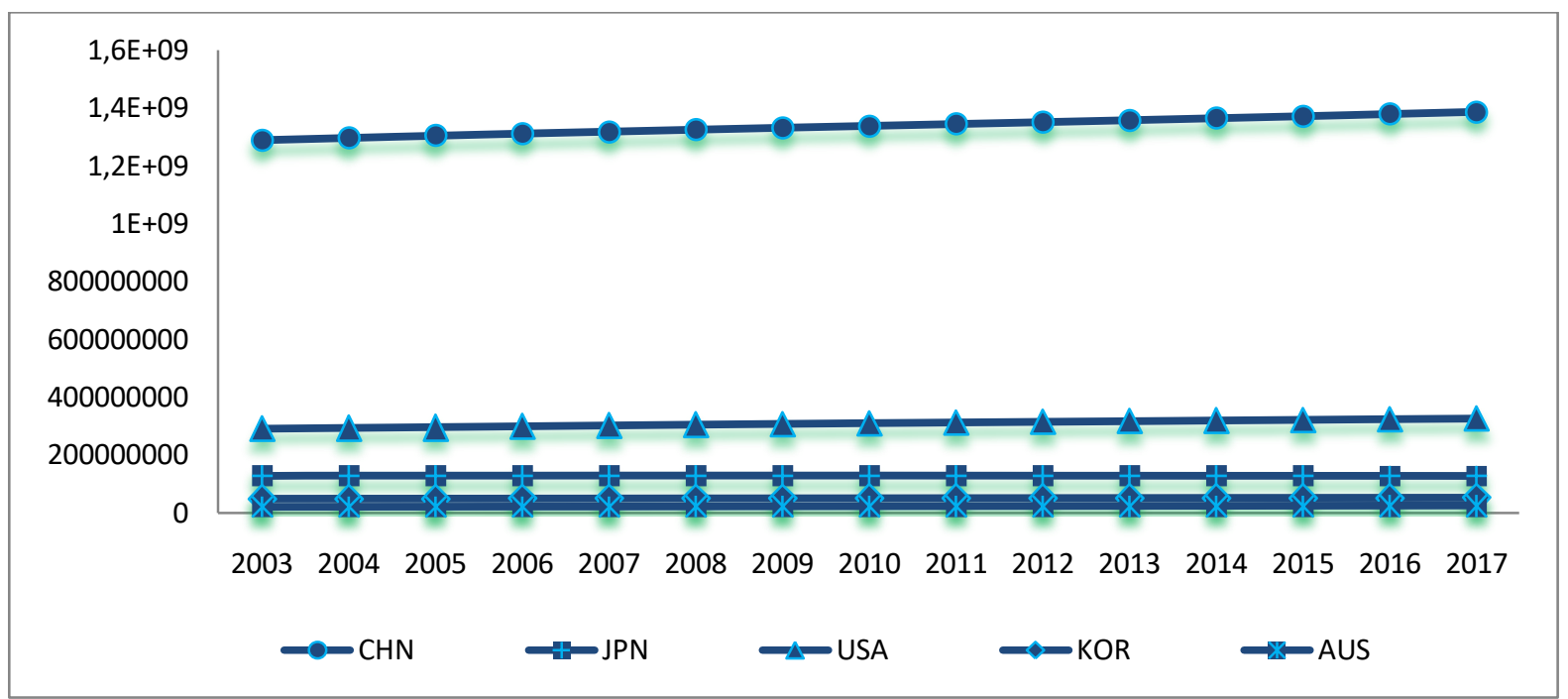

Figure 5 - The Importers' Population from 2003-2017

Figure 7 shows the population of the export destination country has a negative effect on the value of Indonesian tropical timber exports. In this case, each importer country is more focused on improving export performance and limiting imports to enhance economic development in their respective countries. This statement is in line with research conducted by Mankiw (2007), if the population increases in a country and the country is able to improve its export performance, then an increase in population can have a positive effect on the country's economy.

The exchange rate is the ratio between the price of a country's currency with another country's currency. The relative cost of a product can be cheaper or more expensive because the exchange rate influences it. If there is a change in the exchange rate, then the resulting price of the product will also change. In this study, the calculation of exchange rates uses Purchasing Power Parity (PPP) from Penn World Table 9.1 to calculate or convert exchange rates between two countries with one currency, namely the Dollar. The PPP exchange rate differs significantly from the real exchange rate because each country has different standards of living and the prices of goods and services. This concept states that the price of a commodity that is converted to the same currency will be the same in a different country. Additionally, the things which drive the price distinction are tariffs, transportation costs, and non-tariff barriers with a scale of price differences depending on the ability of traded goods (Ward, 2002). PPP exchange rates are used in international comparisons that have been adjusted to the standard of living and prices of products and services in each country (Rodrik, 2008).

Based on the estimation results, the exchange rate variable has a positive and significant effect on the volume of Indonesian tropical wood exports. It is proven by the positive value coefficient, which is 3.98 , and the probability level of 0.007 is smaller than the 
real level $\alpha=0.01$. This number indicates that if there is an increase in the exchange rate by $1 \%$ or in other words, the exchange rate of the trading partner countries will appreciate the dollar, it will increase the export volume by $3.98 \%$. The following is a graph of the exchange rates of the five export destination countries affected by the Dollar from 2003 to 2017:

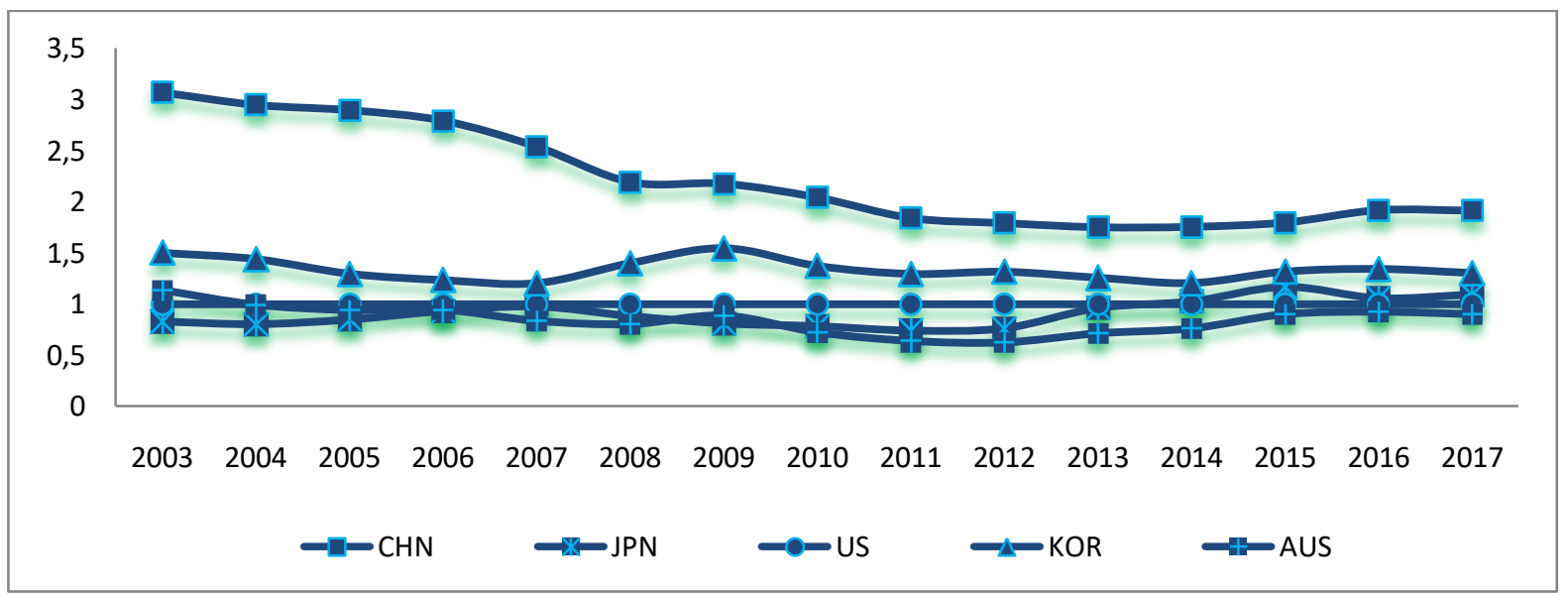

Figure 6 - The Importers' Exchange Rate Against Dollars from 2003-2017

Figure 8 shows the exchange rate that has been adjusted by PPP for each importing country. The exchange rate of export destination countries to US $\$$ has a positive influence on Indonesian exports. In other words, the stronger exchange rates of importing countries against US $\$$ cause an increase in tropical timber exports because when a currency appreciates, countries whose currencies appreciate will import more since it considered profitable.

Distance is one of the considerations in bilateral trade for geographical trade patterns. Distance is a number that shows how far an object changes its position through a specific path. Differences in distances between countries can affect the value of exports because the distance will increase transportation costs and thus reduce trade. Based on the estimation result, the distance between the exporter and importer countries leads to the relationship in accordance with the hypothesis. The coefficient value for the distance variable is $(-3589)$ with a probability value of 0.000 , which is smaller than the real level $\alpha=0.01$. These numbers indicate that every $1 \%$ gap will reduce the import demand of the destination country by $3589 \%$ due to increased trade costs. In accordance with Newton's law of gravity that the farther the distance of the interaction between two objects, the smaller the interaction power. Here is a picture of the static distance of the capital city of Indonesia with the national capitals of China, Japan, the United States, South Korea, and Australia.

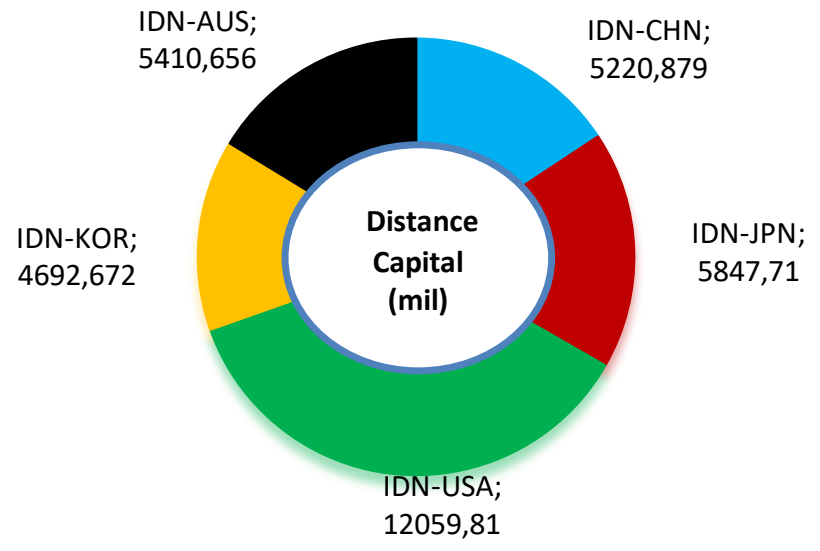

Figure 7 - The Distances between Exporters and Importers 
It is seen in figure 9 that the distance between Indonesia and the United States is further than other countries such as China, Japan, South Korea, and Australia. The greater the distance between countries that will cooperate, the greater the costs involved. The distance between Indonesia and China is closer than Japan and the United States, so that the demand for imports of tropical wood from China is far more. Australia has a relatively shorter distance from Indonesia but, exports of tropical timber to Australia are less than other countries because they must also be adjusted to the number of import needs and economic size of each country. In other words, besides the distance variable, several other factors exist in the model that can affect the demand for tropical timber exports to five export destination countries.

\section{CONCLUSION}

The conclusion of this study based on the estimation results and discussion of the Gravity model on the determinant factors of Indonesian tropical wood exports to five export destination countries namely, China, Japan, the United States, South Korea, and Australia, are due to the variables of the exporter's GDP, importer's GDP, and the exchange rates, which have a significant positive effect on exporting Indonesian tropical timber. If there is any improvement in these variables, it will increase the value of tropical timber exports. The exporter population variable and the distance between exporting countries and importers have a significant negative effect on Indonesian tropical timber exports so that if the two variables increase, it will reduce the value of tropical timber exports. The importer population variable does not have a significant negative effect on the value of tropical timber exports. This statement means that if there is an increase, it will reduce the value of tropical timber exports, but not significantly. To conclude, the dominant factor influences the export value of tropical wood to five consecutive export destination countries is the exchange rate, GDP of exporters, GDP of importers, distance, and population of exporters.

\section{REFERENCES}

1. Bergstrand, J.H.(1985). The gravity equation in international trade: some microeconomic foundations and empirical evidence. The review of economics and statistics; 474-481.

2. Doumbe Doumbe, E. And Belinga, T. (2015). A Gravity Model Analysis for Trade between Cameroon and Twenty-Eight European Union Countries. Open Journal Social Sciences, 3, 114-122.

3. Edward, C. (2005). Potential Trade in Southeast Europe: a Gravity Model Approach. Online. Didapat: www.wiiw.ac.at.balkan.

4. Elshehawy, M.A., Shen, H.F. and Ahmed, R.A. (2014). The Factors Affecting Egypt's Exports: Evidence from the Gravity Model Analysis. Open Journal of Social Sciences, 2, 138-148.

5. Head, K. (2003). Gravity for Beginners. University of British Colombia. Canada.

6. Mankiw, N.G. (2007). Makroekonomi. Edisi Keenam. Liza, F and Nurmawan. Jakarta: Gelora Aksara Pratama.

7. Mareta, B. M. T. (2018). The Impact of ASEAN-Korea Free Trade Agreements on Indonesia Exports of Manufacturing Goods. Etikonomi: Jurnal Ekonomi. 17(2): 161-184.

8. Nandika, D.(2005). Hutan Bagi Ketahanan nasional. Surakarta: Muhammadiah Univerity Press.

9. Nachrowi, N. Djalal and Hardius Usman. (2006). Pendekatan Populer and Praktis Ekonometrika untuk Analisis Ekonomi and Keuangan. Jakarta: LPFE Universitas Indonesia.

10. Nugroho, A. (2014). The Impact of Food Safety Standard on Indonesian Coffee Exports. Procedia Environmental Sciences. 20 (2014) 425-433.

11. Rodrik, D. (2008). The Real Exchange Rate and Economic Growth. Brookings Papers on Economic Activity. USA: Harvard University Press. 
12. Simangunsong, Bintang C.H. (2004). The Economic Perfomance of Indoneia's Forest Sector in the Period 1980-2002. 10 Maret 2019. http://www.rimbawan.com.

13. Sutarno, H, Rifai, M.A, and Nasution, R.E. (1994). Pepohonan Sumber Penghasil Kayu Ekonomi Utama. Bogor: Prosea Indonesia.

14. Tinbergen, J. (1962). Shaping the World Economy; Suggestions for an International Economic Policy. New York: Twentieth Century Fund.

15. Wang, J.Y. (2016). Analysis of The Factors Influencing Japan's Soybean Import Trade: Based on Gravity Model. American Journal of Industrial and Business Management, 6, 109-116.

16. Wahyudi, S.T and Anggita, R.S. (2015). The Gravity Model of Indonesian Bilateral Trade. International Journal of Social and Local Economic Governance. 1(2): 153-156.

17. Ward, Michael, (2002), "Purchasing Power Parities V. Exchange Rates in International Comparisons", Statistical Journal of the United Nations ECE, 19, 261-276. 